\title{
Development and Validation of Specific Carotene Food Composition Tables for Use in Nutritional Epidemiologic Studies for Japanese Populations
}

\author{
Yoshiko Takahashi ${ }^{1,2}$, Satoshi Sasaki ${ }^{1}$ and Shoichiro Tsugane ${ }^{1}$
}

\begin{abstract}
Assessment of dietary intake is important to understand the relationship between nutrition and health. Although the role of specific carotenoids has recently been of great interest, there are no comprehensive food composition tables for intake of specific carotenoids in Japan. We have therefore developed a new carotene food composition table that shows the alpha- and betacarotene values based on an extensive review of the literature (FCT1). Using a 14- or 28-day diet record data of sample population $(n=188)$, we selected 12 important foods to two carotene intakes. We analyzed the carotene contents of the foods, and developed the another composition table in which the food contents were replaced by the analytical values (FCT2). Carotene intakes of the population were significantly different between these two composition tables. However, the correlations between the dietary intake and the serum concentrations were almost identical, i.e., partial correlations using FCT1/FCT2 were $0.32 / 0.30$ and $0.33 / 0.36$ for alpha-carotene and $0.28 / 0.28$ and $0.30 / 0.29$ for beta-carotene in men and women. The similar correlations with the serum concentrations may indicate an comparable value for ranking individuals between the two tables. However, the results were inconclusive for the estimation of absolute intakes. J Epidemiol, $2001 ; 11: 266-275$
\end{abstract}

dietary assessment, epidemiology, nutrition, carotene

\section{INTRODUCTION}

Assessment of dietary intake is important to understand of the relationship between nutrition and health by epidemiological investigation. Dietary assessment depends on the quality of the food composition tables used for nutrient calculation. Japanese food composition tables, however, do not always provide sufficient information such as sampling methods, detailed analytic methods and explanations of missing values.

In Western countries, although findings have not been consistent, several recent epidemiologic studies have reported the relationship between specific carotenoids in foods and the incidence of cancer at several sites ${ }^{1-6}$, cardiovascular disease ${ }^{7}$, and age-related macular degeneration ${ }^{8}$. In Japan, however, there is no report to date of a comprehensive food composition table of specific carotenoids.
In this article, we describe the development of a new carotene food composition table that indicates the values for alpha- and beta-carotene. Firstly, we developed a carotene food composition table using published data on carotene food composition. Secondly, we sampled and analyzed the compositions of foods with high contribution to carotene intakes. Thirdly, the analyzed values were replaced by the literature-based values. Lastly, they were applied to a sample population, and validated by diet-serum relationships.

\section{METHODS}

\section{Development of new composition table using published data}

We extensively searched the English and Japanese literature for reports on the food composition of specific carotenoids. We especially checked all the articles published in the following Japanese journals between 1990 and 1999 using "carotene or

Received May 7, 2001; accepted July 24, 2001.

' Epidemiology and Biostatistics Division, National Cancer Center Research Institute East, Kashiwa, Japan.

- Department of Environmental and Occupational Health, Toho University School of Medicine, Tokyo, Japan.

Address for correspondence : Shoichiro Tsugane, M.D., Epidemiology and Biostatistics Division, National Cancer Center Research Institute East, 6-5-1 Kashiwanoha, Kashiwa-city, Chiba 277-8577, Japan. 
carotenoid, and several food names" in the title as key words: "J Food Sci Tec", "J Jpn Soc Nutr Food Sci", "Jpn J Nutr", "Bull Jpn Soc Sci Fish" and "Nippon Nogeikagaku kaishi". We also collected food composition tables which was used in the published epidemiologic studies on the association between carotene intake and diseases conducted in Western countries. We obtained 6 articles published in Japan ${ }^{914}, 3$ in Finland ${ }^{15-17}$, and the United States' Department of Agriculture (USDA) food composition tables ${ }^{18)}$. The reports published in Japan covered only alpha- and beta-carotene, and no other carotenoids (beta-cryptoxanthin, lutein, zeaxanthin and lycopene) were mentioned. Thus, we developed a composition table only for alpha- and beta-carotene. Gamma-carotene and delta-carotene are determined in only a few vegetables ${ }^{15}$. Furthermore, there are no reports about these carotenes neither in Japan nor in Western countries. Thus, we could not developed food composition tables of these carotenes. According to the literature reviews, the composition ratio of alpha- and beta-carotene was relatively stable, although the analytical values varied widely. The values of "carotene" in the standard food composition table for Japanese foods were almost the sum of the alpha- and beta-carotenes (K. Odaka, personal communication). Therefore, we developed a new carotene composition table by substituting the composition ratios of alpha- and beta-carotene obtained from the literature. Since our new carotene composition table is intended for Japanese populations, we have given priority to the reports published in Japan for the selection. The alpha- and beta-carotene composition of food was determined using the total carotene composition in the standard food composition table of Japanese foods (fourth revised edition) ${ }^{19)}$ and the ratio of alpha- and beta-carotene composition of the food obtained from the literature as follows (Method A):

$$
\mathrm{C}=\mathrm{ST}^{*}\left(\mathrm{R}_{\mathrm{i}} / \mathrm{R}_{\mathbf{t}}\right)(\mu \mathrm{g} / 100 \mathrm{~g} \text { food portion })
$$

where $\mathrm{C}$ is the estimated specific carotene content of a food, ST is the total carotene content in the standard food composition table of the food, $R_{i}$ is the specific carotene content of the food obtained from the literature, $i$ is alpha-carotene or betacarotene, and $R_{t}$ is the total carotene (sum of alpha- and betacarotene) content obtained from the literature.

When specific carotene data were unavailable for a particular food, we used the composition ratio of alpha- and betacarotene of the botanically similar foods with known specific carotene content (Method B). In reports published in Japan, most of the data were analyzed using raw foods. Thus, the carotene content ratios of raw foods were adapted to that of cooked foods. We estimated specific carotene compositions for foods with carotene contents $>0 \mu \mathrm{g} / 100 \mathrm{~g}$ portion. Foods categorized as cooked and prepared foods, the so-called "food group 18" in the standard food composition table, were not included in this study. Among confectioneries, contained at least some carotene, mostly from milk, egg, butter, and color additives. Based on our literature search, these ingredients contain only beta-carotene. Total carotene was thought to be betacarotene in this food group (Method C). Although green leafy vegetables were considered carotene-rich foods, we could obtain data only for a part of these foods. Most green leafy vegetables do not contain alpha-carotene according to the published reports. Total carotene was thought to be beta-carotene in green leafy vegetables (Method C). Algae are also carotenerich foods, but reliable information on the alpha- and betacarotene composition was unavailable. "Nuts and seeds" and most "seasonings and spices" also contain carotene, but we could not obtain their specific carotene composition.

\section{Selection and laboratory analysis of important foods}

Carotene compositions were analyzed for the important foods selected by the following criteria. First, specific carotene intake levels of the four sample populations (see "sample population and data collection" in detail) were calculated with the developed carotene composition table. Next, we selected foods in which alpha- or beta-carotene contributed more than $3 \%$ of the overall intake in each area. The food samples were purchased between June and July in 1999. Three samples were obtained for each item from 3 different stores. Most samples were from local markets, and the cheapest one was selected.

Only the edible part of the foods was used for laboratory analysis. Fifty grams of each sample, $50 \mathrm{~mL}$ of water, and 5 $\mathrm{mL}$ of pyrogallol were mixed together. Ten grams of samples were homogenized and extracted in an Ultra Turrax by 150 $\mathrm{mL}$ of $\mathrm{n}$-hexane / acetone (2:1), then filtered and the food residue extracted several times with $n$-hexane / acetone until the yellow became colorless. The combined carotene extract was mixed with $100 \mathrm{~mL}$ of water for $30 \mathrm{~min}$ at room temperature. After phase separation, the lower phase was removed and shaken again with hexane. The recombined $n$-hexane phases were dried by water-free $\mathrm{Na}_{2} \mathrm{SO}_{4}$ and reduced in the rotation evaporator at $30^{\circ} \mathrm{C}$. Then $25 \mu \mathrm{L}$ of the solution was applied to a high-performance liquid chromatography (HPLC) (Waters, Milford, Mass). The HPLC conditions were as follows: C18 reverse phase column, Wakopak (Wako, Osaka, Japan); mobile phase, methanol: acetonitrile: water $=60: 40: 1$; UV wavelength, 450 ; flow rate, $1.0 \mathrm{~mL} / \mathrm{min}$. The mean value was calculated with the data from triplicate analysis.

\section{Development of table with analytical (FCT2)}

We computed alpha- and beta-carotene composition using the formula (1) for the foods with analytical values. But $R_{i}$ is the analytical specific carotene content of the food and $R_{t}$ is the sum of analytical alpha- and beta-carotene content of the food (Method D). Botanically similar foods were also replaced by analytical values (Method $\mathrm{E}$ ). The composition for these foods in FCT1 were replaced by the new compositions. We referred to this composition table as FCT2. 


\section{Sample population and data collection}

\section{Subjects}

The sample population was a sub-population $(n=221$, aged 44-63 years) from the Japanese Public Health Center-based Prospective Study (JPHC Study) ${ }^{20)}$ living in Iwate, Akita, Nagano, and Okinawa prefectures who kept 28- or 14-day dietary records (DR) in 1994 or 1995 . The subjects were orally informed the purpose and procedure of this study and agreed to the participation by providing diet record and blood sample.

\section{Diet record}

Semi-weighted dietary records from four different seasons (two seasons, i.e., winter and summer only in Okinawa) over seven consecutive days were collected by a method used in the National Nutrition Survey ${ }^{21)}$ with some modifications ${ }^{22,23)}$. Research dieticians instructed the subjects to record all foods and beverages prepared and consumed in a specially designed booklet. The participants were asked to provide detailed descriptions of each food, including the methods of preparation and recipes whenever possible. The dieticians checked the records at each participant's home during the survey and reviewed them in a standardized way after recording.

\section{Blood samples}

A total of $25 \mathrm{~mL}$ serum was collected by venipuncture from all subjects just before the DR in winter and just after the DR in summer. Fasting for at least 5 hours was requested before blood collection. The samples were stored at $-80^{\circ} \mathrm{C}$ until analysis. Serum carotenes were determined by HPLC. Total cholesterol in serum was analyzed enzymatically with an autoanalyzer.

\section{Anthropometric data}

The body mass index (BMI) was computed in all subjects as self-reported weight $(\mathrm{kg})$ divided by height $(\mathrm{m})$ squared.

\section{Validation of two composition tables}

We calculated specific carotene levels of the sample population with the two developed carotene composition tables. The first step was to compare the distributions of each of the aforementioned composition tables. We evaluated the agreement between the two different composition table estimates by comparing mean and median intakes. Because the distributions of the paired differences were not normally distributed, a nonparametric test, the Wilcoxon signed-rank test, was used to determine whether or not the median difference between FCT1 and FCT2 carotene estimates were significantly different from zero. The second step was to validate the two composition tables by comparing the diet-serum relationship for the alphaand beta-carotene using Spearman rank correlation coefficients. Multiple regression analysis was conducted on the serum carotene concentrations and the estimated intakes including possible confounding factors such as BMI, serum cholesterol concentration, alcohol intake, number of cigarettes smoked per day, and age ${ }^{24-2 t}$. Serum total- and beta-carotene showed significant correlations with BMI and alcohol intake. Alpha-carotene showed significant correlations with BMI, alcohol intake, and serum total cholesterol. Therefore the partial correlation coefficients adjusting for these significant variables were computed in each model and presented here. SAS software, release 6.12 (SAS Institute, Cary NC) was used for all statistical computations.

Three subjects (1 man and 2 women) who took carotene containing supplements were excluded from the analysis. Serum carotene reflects the relatively long-term intake such as several weeks ${ }^{28,29)}$. In addition, there are large day-to-day variation in dietary carotenoid intake ${ }^{30-32)}$. Thus, we used serum measurement in summer and 14-day DR data combining two 7-day DR data obtained in winter and summer respectively.

\section{RESULTS}

\section{Development of composition table using published data}

Table 1 shows the number of foods by substitution methods. Among 553 foods in which carotene is $>0 \mu \mathrm{g} / 100 \mathrm{~g}$ portion, substitution methods were found for 341 foods. A suitable substitution method was not found for the remaining 212 foods. The $81.5 \%, 11.1 \%$, and $7.3 \%$ of foods were substituted by Methods A, B and C, respectively. The food compositions of alpha- and beta-carotenes for the 341 foods are listed in Appendix A. Appendix B shows there was only beta-carotene.

\section{Selection and analysis of important foods}

Table 2 presents the contribution rate of food for intake of total-, alpha-, and beta-carotene in the sample population. Ninjin (Daucus carota) was the most important food both for alpha- and beta-carotene intakes in all areas (about $90 \%$ for alpha-carotene, and 32 to $50 \%$ for beta-carotene). No apparent area-difference was observed for alpha-carotene except in the Okinawas, where Nigauri (Momordica charantia) was also important for alpha-carotene intake. In all the areas, hourensou (Spinacia oleracea) mainly contributed to beta-carotene intake. In the Nagano area, Nozawana (Brassica campestris) also largely contributed to beta-carotene intake. In the Okinawa area, mango (Mangifera indica) also acconuted for much betacarotene intake. According to the criteria, we selected 12 foods and collected 72 samples in each area. Ninjin and hourensou were collected in 4 areas. Nira (Allium tuberosum) and tomato (Lycopersicon esculentum) were collected in the Iwate, Akita, and Nagano areas. Komatsuna (Brassica campestris) was collected in the Akita and Nagano areas. Shungiku (Chrysanthemum coronarium) was gathered only in the Akita area. Seiyou-Kabocha (Cucurbita mexima) was obtained from the Iwate and Nagano areas. Nozawana and Ingenmame (Phaseolus vulgaris) were collected only in the Nagano area. 
Table 1. The number of foods by substitution method and food group $\mathrm{a,b}$.

\begin{tabular}{|c|c|c|c|c|c|c|c|c|c|c|}
\hline & \multicolumn{8}{|c|}{ Food with carotene $(>0 \mu \mathrm{g} / 100 \mathrm{~g}$ portion $)$} & \multirow{4}{*}{$\begin{array}{c}\text { Foods without } \\
\text { carotene } \\
(\mu \mathrm{g} / 100 \mathrm{~g} \\
\text { portion }=0)\end{array}$} & \multirow{4}{*}{ Total } \\
\hline & \multicolumn{6}{|c|}{ Substituted } & \multirow{3}{*}{$\begin{array}{c}\text { Not } \\
\text { substituted }\end{array}$} & \multirow{3}{*}{ Total } & & \\
\hline & \multicolumn{3}{|c|}{ Based on literature value } & \multicolumn{2}{|c|}{ Based on analytical value } & \multirow{2}{*}{ Total } & & & & \\
\hline & Method A & Method B & Method C & Method D & Method E & & & & & \\
\hline Cereals & 5 & 1 & 0 & 0 & 0 & 6 & 0 & 6 & 128 & 134 \\
\hline Potatoes and starches & 4 & 0 & 0 & 0 & 0 & 4 & 2 & 6 & 28 & 34 \\
\hline Sugar and sweeteners & 0 & 0 & 0 & 0 & 0 & 0 & 0 & 0 & 25 & 25 \\
\hline Confectioneries & 2 & 0 & 13 & 0 & 0 & 15 & 3 & 18 & 96 & 114 \\
\hline Fats and oils & 0 & 0 & 0 & 0 & 0 & 0 & 0 & 0 & 11 & 11 \\
\hline Nuts and seeds & 0 & 0 & 0 & 0 & 0 & 0 & 29 & 29 & 6 & 35 \\
\hline Pulses & 13 & 0 & 0 & 0 & 0 & 13 & 9 & 22 & 39 & 61 \\
\hline Fishes and shellfishes & 0 & 0 & 1 & 0 & 0 & 1 & 37 & 38 & 295 & 333 \\
\hline Meats & 0 & 0 & 0 & 0 & 0 & 0 & 6 & 6 & 201 & 207 \\
\hline Eggs & 13 & 4 & 0 & 0 & 0 & 17 & 0 & 17 & 3 & 20 \\
\hline Milks & 35 & 0 & 0 & 0 & 0 & 35 & 0 & 35 & 15 & 50 \\
\hline Vegetables & $134(107)$ & $18(14)$ & $11(11)$ & $0(27)$ & $0(4)$ & $163(163)$ & 43 & 206 & 49 & 255 \\
\hline Green \& yellow vegetables & $87(62)$ & $11(11)$ & $8(8)$ & $0(25)$ & $0(0)$ & $106(106)$ & 2 & 108 & 1 & 109 \\
\hline Others & $47(45)$ & $7(3)$ & $3(3)$ & $0(2)$ & $0(4)$ & $57(57)$ & 41 & 98 & 48 & 146 \\
\hline Fruits & $59(58)$ & $15(15)$ & $0(0)$ & $0(1)$ & $0(0)$ & $74(74)$ & 15 & 89 & 44 & 133 \\
\hline Fungi & 0 & 0 & 0 & 0 & 0 & 0 & 0 & 0 & 31 & 31 \\
\hline Algae & 0 & 0 & 0 & 0 & 0 & 0 & 40 & 40 & 4 & 44 \\
\hline Beverages & 10 & 0 & 0 & 0 & 0 & 10 & 2 & 12 & 53 & 65 \\
\hline Seasonings and spices & 3 & 0 & 0 & 0 & 0 & 3 & 26 & 29 & 26 & 55 \\
\hline Total & $278(250)$ & $38(34)$ & $25(25)$ & $0(28)$ & $0(4)$ & $341(341)$ & 212 & 553 & 1054 & 1607 \\
\hline
\end{tabular}

${ }^{3}$ Refer to substitution methods.

${ }^{b}$ Values indicate the number of foods by literature-based substitution (FCT1) and the values in parentheses indicate the number of foods after analytical values were included (FCT2).

Karashina (Brassica juncea), Nigauri, and mango were gathered only in the Okinawa area.

Analytical contents of alpha- and beta-carotene were shown in Table 3. Although slight differences were found for the contents between areas, there were no apparent differences in the content ratio of alpha- and beta-carotene between samples.

The number of foods in the revised composition table by the substitution method was shown in Table 1 (in parentheses). Carotene contents were revised with analytical values for 32 foods (Methods D and E).

\section{Validation of two composition tables}

Mean, standard deviation, and median estimates of daily carotene intakes based on the developed composition tables in the sample populations by sex are shown in Table 4 . The estimated alpha-carotene intakes were higher in FCT1 than in FCT2. Conversely, the estimated beta-carotene intakes were lower in FCT1 than in FCT2. All the median values are significantly different between FCT 1 and FCT2 by Wilcoxon signedrank test. We also calculated and examined them by area, but no apparent area-difference was observed (data not shown). Table 5 shows Spearman correlation coefficients for specific carotenes between the intakes and the corresponding serum concentrations. In both sexes, carotene intakes moderately cor- related with the serum concentrations. Only small differences were found between the results based on FCT1 and FCT2.

\section{DISCUSSION}

Several study groups have developed food composition tables for use in epidemiologic studies by several methods $15,33-37,39$ ), and they have often been evaluated for reliability $33,35,36,39,43)$. Recent interest in the potential health effects of several carotenoids other than their contribution to vitamin A activity has stimulated the development of an accurate composition table for carotenoids in the United States ${ }^{35,36)}$, Finland ${ }^{15-17}$, and other countries.

Although our primary purpose in this study was to develop a carotenoid composition table for Japan, our composition tables were limited only to alpha- and beta-carotenes due to the lack of reliable information on other carotenoids such as beta-cryptoxanthin, lutein, zeaxanthin, and lycopene. Moreover, the reports published in Japan examined only alpha- and betacarotene compositions. Although the literature in other countries referred to other carotenoids, information on original Japanese vegetables such as komatsuna, and nozawana was insufficient. Furthermore, because of the very limited nature of the reports published in Japan, in selecting these reports we 
Table 2. Contribution of foods ${ }^{\mathrm{a}}$ to alpha- and beta-carotene intakes by area based on 14-day dietary record for 88 men and 100 women using a literature-based food composition table (FCT1).

\begin{tabular}{|c|c|c|c|c|c|c|c|c|c|}
\hline \multicolumn{2}{|c|}{ Iwate $(n=47)$} & \multicolumn{2}{|c|}{ Akita $(n=50)$} & \multicolumn{2}{|c|}{ Nagano $(n=44)$} & \multicolumn{2}{|c|}{ Okinawa $(n=47)$} & \multicolumn{2}{|c|}{ Total $(n=188)$} \\
\hline Food & Cumulative \% & Food & Cumulative \% & Food & Cumulative \% & Food & Cumulative $\%$ & Food & Cumulative \% \\
\hline \multicolumn{10}{|l|}{ Alpha-carotene } \\
\hline Ninjin, raw & 92.6 & Ninjin, raw & 91.9 & Ninjin, raw & 90.4 & Ninjin, raw & 94.0 & Ninjin, raw & 92.3 \\
\hline Tomato, raw & 96.0 & Tomato, raw & 95.9 & Tomato, raw & 94.3 & Nigauri, raw & 97.3 & Tomato, raw & 95,7 \\
\hline -..-. & & ---- & & Ingenmame, raw & 97.4 & -..-.. & & $\cdots$ & \\
\hline \multicolumn{10}{|l|}{ Beta-carotene } \\
\hline Ninjin, raw & 46.5 & Ninjin, raw & 33.1 & Ninjin, raw & 32.2 & Ninjin, raw & 49.9 & Ninjin, raw & 39.9 \\
\hline Hourensou, raw & 62.2 & Hourensou, raw & 53.0 & Nozawana, salted & 49.3 & Hourensou, raw & 61.8 & Hourensou, raw & 54.2 \\
\hline Nira, raw & 67.3 & Nira, raw & 59.1 & Hourensou, raw & 58.3 & Mango & 66.3 & Nozawana, salted & 59.0 \\
\hline Seiyou-Kabocha, rav & aw 70.4 & Komatsuna, raw & 65.1 & Komatsuna, raw & 65.1 & Karashina, raw & 70.3 & Nira, raw & 63.7 \\
\hline..--- & & Shungiku, raw & 68.7 & Nira, raw & 69.7 & -..-- & & Komatsuna, raw & 67.9 \\
\hline$\cdots+.$. & & $\ldots . .$. & & Seiyou-Kabocha, raw & 73.7 & $-\cdots$ & & Seiyou-Kabocha, raw & 71.0 \\
\hline$\cdots$ & & ---- & & Tomato, raw & 76.9 & $\cdots+.$. & & ----- & \\
\hline \multicolumn{10}{|l|}{ Total carotene } \\
\hline Ninjin, raw & 50.6 & Ninjin, raw & 38.2 & Ninjin, raw & 37.2 & Ninjin, raw & 56.7 & Ninjin, raw & 45.2 \\
\hline Hourensou, raw & 62.4 & Hourensou, raw & 54.0 & Nozawana, salted & 50.9 & Hourensou, raw & 66.0 & Hourensou, raw & 56.3 \\
\hline Nira, raw & 66.2 & Nira. raw & 20.7 & Hourensou, raw & 58.1 & Mango & 69.5 & Nozawana, salted & 60.0 \\
\hline$-\cdots-\cdot$ & & Komatsuna, raw & 63.6 & Komatsuna, raw & 63.5 & Karashina, raw & 72.6 & Nira, raw & 63.7 \\
\hline$-\cdots--$ & & -...- & & Nira, raw & 67.2 & $\cdots$ & & Komatsuna, raw & 67.0 \\
\hline$-\cdots--$ & & 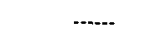 & & Tomato, raw & 70.5 & $\cdots+-\cdot$ & & ---- & \\
\hline$\ldots$ & & $\cdots+\cdots$ & & Seiyou-Kabocha, raw & 73.7 & --- & & $\ldots . .$. & \\
\hline
\end{tabular}

${ }^{a}$ Ninjin= Daucus carota Tomato $=$ Lycopersicon esculentum, Hourensou= Spinacia oleracea, Nira $=$ Allium tuberosum;

Seiyou-Kabocha $=$ Cucurbita mexima $;$ Komatsuna= Brassica campestris; Shungiku= Chrysanthemum coronarium;

Ingenmame $=$ Phaseolus vulgaris $;$ Nozawana $=$ Brassica campestris $;$ Nigauri $=$ Momordica charantia $;$

Mango= Mangifera indica $;$ Karashina $=$ Brassica juncea $($ scientific names are in Italics).

Table 3. Analytical contents of alpha- and beta-carotene $(\mu \mathrm{g} / 100 \mathrm{~g}$ food portion).

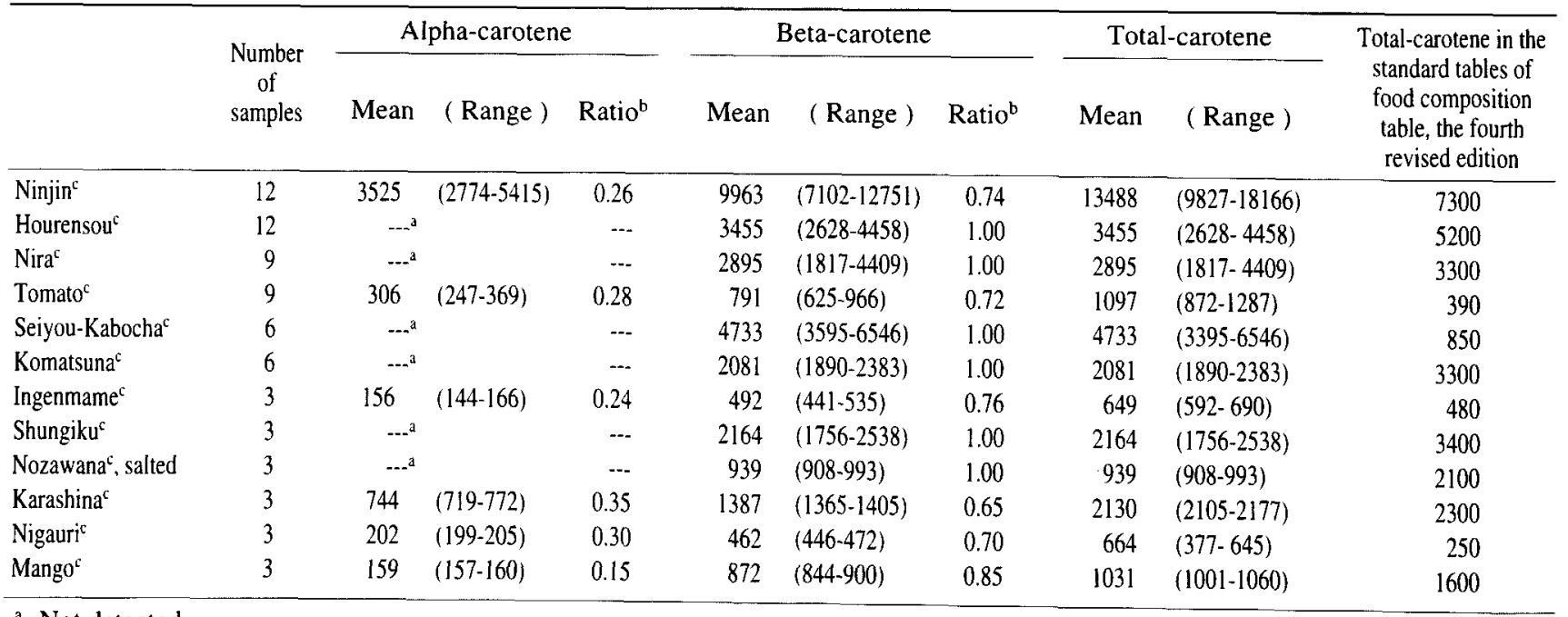

a Not detected.

${ }^{\text {b }}$ Composition ratio of alpha- or beta-carotene to total carotene.

c See Table 2 for detailed information. 
Table 4. Daily carotene intakes $(\mu \mathrm{g})$ estimated using developed carotene food composition tables ${ }^{\mathrm{a}}$.

\begin{tabular}{|c|c|c|c|c|c|c|}
\hline & \multicolumn{2}{|c|}{ FCT 1} & \multicolumn{2}{|c|}{ FCT2 } & \multirow{2}{*}{$\begin{array}{c}\text { Statistical } \\
\text { differences }^{b}\end{array}$} & \multirow{2}{*}{ Correlation } \\
\hline & Mean (SD) & Median & Mean (SD) & Median & & \\
\hline \multicolumn{7}{|l|}{ Men $(n=88)$} \\
\hline Total-carotene & $3420(1506)$ & 2969 & \multicolumn{2}{|c|}{--.--c c } & & \\
\hline Alpha-carotene & $555 \quad(327)$ & 437 & $497 \quad(303)$ & 385 & $\mathrm{p}<0.001$ & 0.99 \\
\hline Beta-carotene & $2670(1217)$ & 2359 & $2728(1222)$ & 2416 & $\mathrm{p}<0.001$ & 0.99 \\
\hline \multicolumn{7}{|l|}{ Women $(n=100)$} \\
\hline Total-carotene & 3347 (1392) & 3160 & \multicolumn{2}{|c|}{$\ldots$} & & \\
\hline Alpha-carotene & $515 \quad(269)$ & 456 & $462 \quad(238)$ & 394 & $\mathrm{p}<0.001$ & 0.97 \\
\hline Beta-carotene & 2644 (1149) & 2492 & $2697(1160)$ & 2522 & $\mathrm{p}<0.001$ & 0.99 \\
\hline
\end{tabular}

a $\mathrm{SD}=$ standard deviation; FCT1 = literature-based table; $\mathrm{FCT} 2=$ table developed by combining literature and analytical values (see text for detail).

${ }^{b}$ Statistical difference of median between FCT1 and FCT2 by Wilcoxon signed-rank test.

' Same as FCT1 (see text for details).

d Spearman rank correlation coefficient between FCT1 and FCT2 estimates.

Table 5. Spearman rank correlation coefficients between carotene intakes $(\mu \mathrm{g} / \mathrm{day})$ and corresponding serum concentrations $(\mathrm{mg} / \mathrm{mL})$ in a sample population.

\begin{tabular}{|c|c|c|c|c|}
\hline & \multicolumn{2}{|c|}{ Men } & \multicolumn{2}{|c|}{ Women } \\
\hline & $\mathrm{FCT} 1^{\mathrm{a}}$ & $\mathrm{FCT}^{\mathrm{a}}$ & $\mathrm{FCT1}^{\mathrm{a}}$ & $\mathrm{FCT}^{\mathrm{a}}$ \\
\hline Simple correlations & \multicolumn{2}{|c|}{$\mathrm{n}=88$} & \multicolumn{2}{|c|}{$\mathrm{n}=100$} \\
\hline Total carotene & 0.28 & $--^{b}$ & 0.25 & $--{ }^{b}$ \\
\hline Alpha-carotene & 0.35 & 0.34 & 0.36 & 0.38 \\
\hline Beta-carotene & 0.27 & 0.26 & 0.24 & 0.24 \\
\hline Partial correlations ${ }^{c}$ & \multicolumn{2}{|c|}{$n=84$} & \multicolumn{2}{|c|}{$n=97$} \\
\hline Total carotene & 0.28 & $--^{b}$ & 0.30 & $---^{b}$ \\
\hline Alpha-carotene & 0.32 & 0.30 & 0.33 & 0.36 \\
\hline Beta-carotene & 0.28 & 0.28 & 0.30 & 0.29 \\
\hline
\end{tabular}

a See Table 4 for the detailed definitions.

${ }^{b}$ Same as FCT1 (see text for details).

c Partial correlation coefficients adjusted for body mass index (BMI) and alcohol intake for total- and beta-carotene, and BMI, alcohol intake, and serum total cholesterol for alphacarotene.

could not sufficiently consider the data quality of the measuring and sampling methods used in them. Mangels et al. developed a carotenoid composition table for American foods using reference values obtained from more than 180 articles published in the US and other countries ${ }^{36)}$. Further literature research with larger sample size and reasonable quality is needed to obtain adequate food composition data on carotenoids in Japan.

Total carotene, alpha- and beta-carotene were mainly derived from Ninjin. Total-carotene and beta-carotene were derived from Hourensou and Nozawana, and alpha-carotene was derived from Tomato. Ninjin and Hourensou were also major sources of total carotene intake in two previous studies in Japan ${ }^{44,45)}$.

Both analytical and reference values varied widely between sampled foods because many factors such as varietal differences, variable growth and storage, different geographic locations, and seasons, affect the carotene composition in foods ${ }^{9,36}$. This may seriously distort the results, especially in the development of a composition table using reference values rather than analytical values obtained from the foods actually consumed by a target population. Despite this assumption, the two composition tables similarly ranked the sample subjects according to each carotene intake when the serum carotene concentration was used as the gold standard (Table 5). The result indicates that analysis of foods consumed by a target 
population, at least with the method used in this study, may not improve results for ranking individuals by intakes. Several studies reported correlations for carotenes between the intakes assessed with DR and the serum or plasma concentrations in Western populations ${ }^{27,46}$. The correlations observed in the present study were comparable to or slightly lower than the previously reported values. But FCT1, which was developed using only reference values, may be more useful in nutritional epidemiologic studies conducted in various populations in Japan, because the analytical values of foods used in this study may not be considered representative. Moreover, we could not examine which composition table was preferable for use in the study to estimate "absolute" intake levels in the absence of a gold standard.

In conclusion, we developed a carotene composition table with food compositions obtained from the literature and analytical values for use in nutritional epidemiologic studies for Japanese populations. FCT1 is readily available for non-profit use only on the authors' website (http://www.east.ncc.go.jp/epi). They request, however that this article be cited when a study in which the data, even in part, have been published or made available to the public. The composition table may be useful for studies on the association between alpha- and beta-carotene intakes and health status in Japanese populations. Its reliability for estimation of estimate absolute intakes, however, is not yet confirmed.

Appendix A. Developed (substituted) alpha- and beta-carotene food composition table.

\begin{tabular}{|c|c|c|c|c|c|c|c|c|c|}
\hline $\begin{array}{l}\text { Food } \\
\text { code }^{a}\end{array}$ & $\begin{array}{l}\text { Total carotene } \\
(\mu \mathrm{g} / 100 \mathrm{~g} \\
\text { food portion) }\end{array}$ & $\begin{array}{l}\text { Alpha-carotene } \\
\text { ( } \mu \mathrm{g} / 100 \mathrm{~g} \\
\text { food portion) }\end{array}$ & $\begin{array}{l}\text { Beta-carotene } \\
(\mu \mathrm{g} / 100 \mathrm{~g} \\
\text { food portion) }\end{array}$ & $\begin{array}{c}\text { Method of } \\
\text { substituition }^{b}\end{array}$ & $\begin{array}{l}\text { Food } \\
\text { code }^{\mathrm{a}}\end{array}$ & $\begin{array}{l}\text { Total carotene } \\
(\mu \mathrm{g} / 100 \mathrm{~g} \\
\text { food portion })\end{array}$ & $\begin{array}{c}\text { Alpha-carotene } \\
(\mu \mathrm{g} / 100 \mathrm{~g} \\
\text { food portion })\end{array}$ & $\begin{array}{l}\text { Beta-carotene } \\
(\mu \mathrm{g} / 100 \mathrm{~g} \\
\text { food portion) }\end{array}$ & $\begin{array}{l}\text { Method of } \\
\text { substituition }^{b}\end{array}$ \\
\hline $1-63$ & 180 & 71 & 109 & A & $13-19 b$ & 400 & 34 & 366 & A \\
\hline $1-64$ & 200 & 79 & 121 & A & $13-19 c$ & 42 & 4 & 38 & A \\
\hline $1-65$ & 210 & 83 & 127 & A & $13-19 d$ & 36 & 3 & 33 & A \\
\hline $1-66$ & 160 & 63 & 97 & A & $13-19 \mathrm{e}$ & 65 & 6 & 59 & A \\
\hline $1-67$ & 140 & 55 & 85 & B & $13-20 a$ & 160 & 14 & 146 & A \\
\hline $1-68$ & 100 & 39 & 61 & A & $13-24 a$ & 18 & 4 & 14 & A \\
\hline $4-63 a$ & 180 & 71 & 109 & A & $13-24 b$ & 75 & 20 & 55 & A \\
\hline $12-6 a$ & 480 & 328 & 152 & A & $13-26 a$ & 120 & 10 & 110 & A \\
\hline $12-6 b$ & 500 & 337 & 163 & A & $13-26 b$ & 80 & 6 & 74 & A \\
\hline $12-17 a$ & 620 & 565 & 55 & A & $13-26 c$ & 120 & 10 & 110 & A \\
\hline $12-17 b$ & 520 & 474 & 46 & A & $13-27$ & 320 & 15 & 305 & A \\
\hline $12-35 a$ & 290 & 229 & 61 & A & $13-38 a$ & 19 & 11 & 8 & A \\
\hline $12-35 b$ & 340 & 260 & 80 & A & $13-38 b$ & 26 & 16 & 10 & A \\
\hline $12-36$ & 8700 & 117 & 8583 & A & $13-42$ & 85 & 51 & 34 & B \\
\hline $12-38 a$ & 310 & 21 & 289 & B & $13-43$ & 32 & 3 & 29 & B \\
\hline $12-38 b$ & 320 & 22 & 298 & B & $13-46 a$ & 750 & 63 & 688 & B \\
\hline $12-80 \mathrm{a}$ & 2000 & 77 & 1923 & $\mathrm{~A}$ & $13-49$ & 12 & 1 & 11 & $\mathrm{~B}$ \\
\hline $12-80 b$ & 20000 & 769 & 19231 & $\mathrm{~A}$ & $13-50$ & 80 & 7 & 73 & B \\
\hline $12-83 a$ & 44 & 22 & 22 & A & $13-51$ & 90 & 8 & 83 & $\mathrm{~B}$ \\
\hline $12-83 b$ & 44 & 22 & 22 & A & $13-54$ & 10 & 7 & 3 & B \\
\hline $12-84 a$ & 60 & 30 & 30 & A & $13-55$ & 13 & 9 & 4 & B \\
\hline $12-84 b$ & 75 & 38 & 19 & A & $13-58$ & 12 & 1 & 11 & $\mathrm{~A}$ \\
\hline $12-85$ & 390 & 86 & 304 & A & $13-62$ & 6 & 4 & 2 & B \\
\hline $12-86 c$ & 480 & 97 & 383 & A & $13-63$ & 1400 & 88 & 1313 & A \\
\hline $12-86 e$ & 2000 & 46 & 1954 & $\mathrm{~A}$ & $13-64$ & 27 & 19 & 8 & A \\
\hline $12-92 a$ & 250 & 123 & 127 & $\mathrm{~A}$ & $13-65$ & & 577 & 263 & A \\
\hline $12-92 b$ & 280 & 138 & 142 & A & $13-75$ & 6 & 4 & 2 & B \\
\hline $12-94 a$ & 7300 & 2263 & 5037 & A & $13-76$ & 14 & 9 & 5 & B \\
\hline $12-94 b$ & 8300 & 2590 & 5710 & A & $13-77$ & 110 & 9 & 101 & $\mathrm{~B}$ \\
\hline $12-125 a$ & 400 & 9 & 391 & A & $13-80 b$ & 450 & 5 & 446 & A \\
\hline $12-125 b$ & 330 & 6 & 266 & A & $13-88$ & 11 & 3 & 8 & A \\
\hline $13-1$ & 120 & 9 & 25 & A & $13-90$ & 9 & 2 & 7 & A \\
\hline $13-11$ & 12 & 3 & 9 & B & $16-19 a$ & 21000 & 1470 & 19530 & A \\
\hline $13-17 a$ & 60 & 5 & 55 & $\mathrm{~A}$ & $16-20$ & 29000 & 7614 & 21386 & A \\
\hline $13-17 b$ & 120 & 10 & 110 & $\mathrm{~A}$ & $16-21 a$ & 13000 & 910 & 12090 & A \\
\hline 13-18a & 60 & 5 & 55 & $\mathrm{~A}$ & $16-22 a$ & 13000 & 910 & 12090 & A \\
\hline $13-18 b$ & 120 & 10 & 110 & A & $16-23 a$ & 14000 & 1400 & 12600 & A \\
\hline $13-19 a$ & 75 & 6 & 69 & A & $16-25 a$ & 7000 & 598 & 6402 & A \\
\hline
\end{tabular}

${ }^{a}$ Food code used in the standard tables of food composition in Japan, the fourth revised edition ${ }^{19)}$.

bee text for methods of substitution. 
Appendix B. Foods of which carotene was only beta-carotene (alpha-carotene was not detected or negligible) by literature-based approach.

\begin{tabular}{|c|c|}
\hline Method of substitution a & Food code ${ }^{b}$ \\
\hline A & $\begin{array}{l}2-5 \mathrm{a}, 2-5 \mathrm{~b}, 2-5 \mathrm{c}, 2-6,4-29,7-7 \mathrm{a}, 7-7 \mathrm{~b}, 7-8,7-11,7-12,7-15 \mathrm{a}, 7-15 \mathrm{~b}, 7-16,7-17,7-19,7-27,7-40 \mathrm{a}, 7-40 \mathrm{~b}, \\
10-5 \mathrm{a}, 10-5 \mathrm{~b}, 10-5 \mathrm{c}, 10-6,10-7,10-8,10-9 \mathrm{a}, 10-9 \mathrm{~b}, 10-10,10-11,10-14,10-15,10-16,11-1,11-2,11-3 \mathrm{a}, \\
11-3 \mathrm{~b}, 11-5 \mathrm{~b}, 11-6 \mathrm{a}, 11-6 \mathrm{~b}, 11-7 \mathrm{a}, 11-7 \mathrm{~b}, 11-9 \mathrm{a}, 11-9 \mathrm{~b}, 11-11 \mathrm{a}, 11-11 \mathrm{~b}, 11-12,11-14,11-15,11-16, \\
11-17 \mathrm{~b}, 11-18,11-19,11-20,11-22 \mathrm{a}, 11-22 \mathrm{~b}, 11-22 \mathrm{c}, 11-22 \mathrm{~d}, 11-22 \mathrm{e}, 11-22 \mathrm{f}, 11-22 \mathrm{~g}, 11-22 \mathrm{~h}, 11-22 \mathrm{i}, \\
11-23,11-24,11-25,11-28,11-29,12-2 \mathrm{a}, 12-2 \mathrm{~b}, 12-3 \mathrm{a}, 12-3 \mathrm{~b}, 12-4 \mathrm{a}, 12-4 \mathrm{~b}, 12-8 \mathrm{a}, 12-8 \mathrm{~b}, 12-9 \mathrm{a}, 12-9 \mathrm{~b}, \\
12-10 \mathrm{a}, 12-10 \mathrm{~b}, 12-11,12-14 \mathrm{a}, 12-14 \mathrm{~b}, 12-15 \mathrm{a}, 12-15 \mathrm{~b}, 12-15 \mathrm{c}, 12-15 \mathrm{~d}, 12-18 \mathrm{a}, 12-18 \mathrm{~b}, 12-19 \mathrm{a}, 12-19 \mathrm{~b}, \\
12-20 \mathrm{a}, 12-20 \mathrm{~b}, 12-24 \mathrm{a}, 12-24 \mathrm{~b}, 12-25 \mathrm{a}, 12-25 \mathrm{~b}, 12-25 \mathrm{c}, 12-26 \mathrm{a}, 12-26 \mathrm{~b}, 12-27 \mathrm{a}, 12-27 \mathrm{~b}, 12-27 \mathrm{c}, 12-30 \mathrm{a}, \\
12-30 \mathrm{~b}, 12-32 \mathrm{a}, 12-32 \mathrm{~b}, 12-34 \mathrm{a}, 12-34 \mathrm{~b}, 12-34 \mathrm{c}, 12-39 \mathrm{a}, 12-39 \mathrm{~b}, 12-46,12-48,12-49 \mathrm{a}, 12-49 \mathrm{~b}, 12-50, \\
12-53 \mathrm{a}, 12-53 \mathrm{~b}, 12-54,12-55 \mathrm{a}, 12-55 \mathrm{~b}, 12-55 \mathrm{c}, 12-65,12-66,12-72,12-73,12-74 \mathrm{a}, 12-74 \mathrm{~b}, 12-77 \mathrm{a}, \\
12-77 \mathrm{~b}, 12-86 \mathrm{a}, 12-86 \mathrm{~b}, 12-86 \mathrm{~d}, 12-87 \mathrm{a}, 12-87 \mathrm{~b}, 12-87 \mathrm{c}, 12-87 \mathrm{~d}, 12-88,12-89,12-91 \mathrm{a}, 12-93 \mathrm{a}, 12-93 \mathrm{~b}, \\
12-96,12-97,12-98 \mathrm{a}, 12-98 \mathrm{~b}, 12-99,12-101 \mathrm{a}, 12-101 \mathrm{~b}, 12-101 \mathrm{c}, 12-104,12-108 \mathrm{a}, 10-108 \mathrm{~b}, 12-109 \mathrm{a}, \\
12-109 \mathrm{~b}, 12-110 \mathrm{a}, 12-110 \mathrm{~b}, 12-113 \mathrm{a}, 12-113 \mathrm{~b}, 12-114 \mathrm{a}, 12-114 \mathrm{~b}, 12-117 \mathrm{a}, 12-117 \mathrm{~b}, 12-120,12-121 \mathrm{a}, \\
12-121 \mathrm{~b}, 12-122 \mathrm{a}, 12-122 \mathrm{~b}, 12-123 \mathrm{a}, 12-123 \mathrm{~b}, 12-137 \mathrm{a}, 12-137 \mathrm{~b}, 12-137 \mathrm{~b}, 12-138 \mathrm{a}, 12-138 \mathrm{~b}, 12-139 \mathrm{a}, \\
12-139 \mathrm{~b}, 12-140,12-141,13-2,13-3,13-4,13-5,13-6,13-21 \mathrm{a}, 12-21 \mathrm{~b}, 13-22,13-23 \mathrm{a}, 13-25,13-31, \\
13-32 \mathrm{a}, 13-32 \mathrm{~b}, 13-45,13-47,13-48,13-59 \mathrm{a}, 13-59 \mathrm{~b}, 13-60,13-61,13-66 \mathrm{a}, 13-66 \mathrm{~b}, 13-68,13-69,13-70, \\
13-71,13-73,13-79,13-80 \mathrm{a}, 13-81 \mathrm{a}, 13-81 \mathrm{~b}, 13-83 \mathrm{a}, 13-84 \mathrm{a}, 16-24 \mathrm{a}, 16-26 \mathrm{a}, 16-27 \mathrm{a}, 16-31,17-6 \mathrm{a}, \\
17-6 \mathrm{~b}, 17-6 \mathrm{c}\end{array}$ \\
\hline B & $\begin{array}{l}10-1,10-2,10-3,10-4,12-12 a, 12-12 b, 12-12 c, 12-28 a, 12-28 b, 12-64 a, 12-64 b, 12-82 a, 12-82 b, 12-102 a, \\
12-102 b, 12-102 c, 12-116 a, 12-116 b, 12-119 a, 12-119 b, 13-56,13-78\end{array}$ \\
\hline $\mathrm{C}$ & $\begin{array}{l}4-7,4-15,4-43,4-45,4-46,4-49,4-50,4-51,4-52,4-53,4-67,4-73 a, 4-74,8-88 c, 12-13 a, 12-13 b, 12-76, \\
12-79 a, 12-90,12-132 a, 12-132 b, 12-132 b, 12-133,12-134 a, 12-134 b\end{array}$ \\
\hline
\end{tabular}

a See text for methods of substitution.

${ }^{b}$ Food code used in the standard tables of food composition in Japan, the fourth revised edition.

\section{ACKNOWLEDGEMENTS}

The authors wish to thank the local staff in each study area. We are grateful to Dr. Fusao Ushio, Dr. Tomoyuki Hanaoka, and Dr. Minoru Sugita for their technical advice. We also thank Ms. Chieko Kanai for her laboratory work. This work was supported by Grants-in-Aid for Cancer Research and for the Second Term Comprehensive Ten-Year Strategy for Cancer Control from the Ministry of Health and Welfare of Japan and for Grants-in-Aid for Scientific Research from the Ministry of Education, Science, Sports and Culture of Japan.

\section{REFERENCES}

1. Le Marchand L, Hankin JH, Kolonel LN, et al. Intake of specific carotenoids and lung cancer risk. Cancer Epidemiol Biomarkers Prev, 1993; 2: 183-187.

2. Speizer FE, Colditz GA, Hunter DJ, Rosner B, Hennekens C. Prospective study of smoking, antioxidant intake, and lung cancer in middle-aged women (USA). Cancer Causes Control, 1999; 10: 475-482.

3. Knekt P, Jarvinen R, Teppo L, Aromaa A, Seppanen R. Role of various carotenoids in lung cancer prevention. $J$ Natl Cancer Inst, 1999; 91: 182-184.

4. Voorrips LE, Goldbohm RA, Brants HA, et al. A prospective cohort study on antioxidant and folate intake and male lung cancer risk. Cancer Epidemiol Biomarkers Prev, 2000; 9: 357-365.

5. Garcia-Closas R, Gonzalez CA, Agudo A, Riboli E. Intake of specific carotenoids and flavonoids and the risk of gastric cancer in Spain. Cancer Causes Control, 1999; 10: 71-75.

6. Michaud DS, Feskanich D, Rimm EB, et al. Intake of specific carotenoids and risk of lung cancer in 2 prospective US cohorts. Am J Clin Nutr, 2000; 72: 990-997.

7. Ascherio A, Rimm EB, Hernan MA, et al. Relation of consumption of vitamin $\mathrm{E}$, vitamin $\mathrm{C}$, and carotenoids to risk for stroke among men in the United States. Ann Intern Med, 1999; 130: 963-970.

8. Seddon JM, Ajani UA, Sperduto RD, et al. Dietary carotenoids, vitamins $\mathrm{A}, \mathrm{C}$, and $\mathrm{E}$, and advanced agerelated macular degeneration. Eye Disease Case Control Study Group. JAMA, 1994; 272: 1413-1420.

9. Kon M, Shimba R. Changes in carotenoid composition during preparation and storage of frozen and freeze-dried squash. J Food Sci Tec, 1989; 36: 619-624 (in Japanese).

10. Izaki Y, Yoshida K, Hidaka K, Toda K. Chlorophylls, carotenes and tocopherols in green vegetables and their relationship. J Jpn Soc Nutr Food Sci, 1986; 39: 485-493 (in Japanese).

11. Watanabe K, Hirota S, Takahashi B. Determination of chlorophyll and carotenoid pigment in Kiwifruit. J Food 
Sci Tec, 1986; 33: 616-620 (in Japanese).

12. Kobayashi $\mathrm{K}$, Iso $\mathrm{H}$, Akuta $\mathrm{S}$. On the composition of carotenoids in loquat fruits. J Food Sci Tec, 1978; 25 : 191-195 (in Japanese).

13. Kitada Y, Tamase K, Sasaki M, Yamazoe Y, Maeda Y, Yamamoto M, Yonetani T. Determination of L-ascorbic acid, tocopherol, carotene and chlorophyll in various teas. J Food Sci Tec, 1989; 36: 927-933 (in Japanese).

14. Hirota $\mathrm{S}, \mathrm{Kon} \mathrm{M}$. Carotenoids in vegetables and fruits. Jpn J Nutr, 1993; 51: 293-316 (in Japanese).

15. Heinonen MI, Ollilainen V, Linkola EK, Varo PT, Koivistoinen PE. Carotenoids in Finnish foods: vegetables, fruits and berries. J Agric Food Chem, 1989; 37: 655-659.

16. Ollilainen V, Heinonen M, Linkola E, Varo P, Koivistoinen $P$. Carotenoids and retinoids in Finnish foods: dairy products and eggs. J Dairy Sci, 1989; 72: 2257-2265.

17. Heinonen M, Ollilainen V, Linkola E, Varo P, Koivistoinen P. Carotenoids and retinoids in Finnish foods: cereal and bakery products. Cereal Chem, 1989; 4 : 270-273.

18. U.S. Department of Agriculture, Agricultural Research Service. 1998. USDA-NCC Carotenoid Database for U.S. Foods.

19. Science and Technology Agency. Standard tables of food composition in Japan. The fourth revised edition. Printing Bureau, Ministry of Finance, Tokyo, 1982 (in Japanese).

20. Tsugane S, Fahey MT, Sasaki S, Baba S. Alcohol consumption and all-cause and cancer mortality among middle-aged Japanese men: seven-year follow-up of the JPHC study cohort 1. Am J Epidemiol, 1999; 150: 12011207.

21. Ministry of Health and Welfare. Kokumin Eiyou No Genjo (Results of National Nutrition Survey, 1993). Daiichi Shuppan Publishers, Tokyo, 1994 (in Japanese).

22. Tsubono Y, Sasaki S, Kobayashi M, Akabane M, Tsugane S. Food composition and empirical weight methods in predicting nutrient intakes from food frequency questionnaire. Ann Epidemiol, 2001; 11: 213-218.

23. Kobayashi M, Sasaki S, Kawabata T, et al. Single measurement of serum phospholipid fatty acid as a biomarker of specific fatty acid intake in middle-aged Japanese men. Eur J Clin Nutr, 2001; 55: 643-650.

24. Ito $Y$, Shima $Y$, Ochiai J, et al. Effects of the consumption of cigarettes, alcohol and food on serum concentrations of carotenoids, retinol and tocopherols in healthy inhabitants living in a rural area of Hokkaido. Jpn J Hygiene, 1991; 46: 874-881.

25. Tsubono Y, Tsugane S, Gey KF. Differential effects of cigarette smoking and alcohol consumption on the plasma levels of carotenoids in middle-aged Japanese men.
Jpn J Cancer Res, 1996; 87: 563-569.

26. Brandy WE, Mares-Perlman JA, Bowen P, et al. Human serum carotenoid concentrations are related physiologic and lifestyle factors. J Nutr, 1996; 126: 129-137.

27. Carroll YL, Corridan BM, Morrissey PA. Carotenoids in young and elderly healthy humans: dietary intakes, biochemical status and diet-plasma relationships. Eur J Clin Nutr, 1999; 53: 644-653.

28. Micozzi MS, Brown ED, Edwards BK, et al. Plasma carotenoid response to chronic intake of selected foods and $\beta$-carotene supplements in men. Am J Clin Nutr, 1992; 55: 1120-1125.

29. Castantino JP, Kuller LH, Begg L, Redmond CK, Bates MW. Serum level changes after administration of a pharmacologic dose of beta-carotene. Am J Clin Nutr, 1988; 48: $1277-1283$.

30. Ogawa K, Tsubono Y, Nishino $\mathrm{Y}$, et al. Inter- and intraindividual variation of food and nutrient consumption in a rural Japanese population. Eur J Clin Nutr, 1999; 52: 781-785.

31. Nelson M, Black AE, Morris JA, Cole TJ. Between- and within-subject variation in nutrient intake from infancy to old age: estimating the number of days required to rank dietary intakes with desired precision. Am J Clin Nutr, 1989; 50: 155-167.

32. Willett W. Nutritional epidemiology. Oxford University Press, New York, 1990.

33. Lurie DG, Holden JM, Schubert A, Wolf WR, Miller-Ihli NJ. The copper content of foods based on a critical evaluation of published analytical data. J Food Comp Anal, 1989; 2: 298-316.

34. Coates RJ, Eley JW, Block G, et al. An evaluation of a food frequency questionnaire for assessing dietary intake of specific carotenoids and vitamin $E$ among low-income black women. Am J Epidemiol, 1991; 134: 658-671.

35. Chug-Ahuja JK, Holden JM, Forman MR, et al. The development and application of a carotenoid database for fruits, vegetables, and selected multicomponent foods. J Am Diet Assoc, 1993; 93: 318-323.

36. Mangels AR, Holden JM, Beecher GR, Forman MR, Lanza E. Carotenoid content of fruits and vegetables: an evaluation of analytic data. J Am Diet Assoc, 1993; 93: 284-296.

37. Scott KJ, Thurnham DI, Hart DJ, Bingham SA, Day K. The correlation between the intake of lutein, lycopene and beta-carotene from vegetables and fruits, and blood plasma concentrations in a group of women aged 50-65 years in the UK. Br J Nutr, 1996; 75: 409-418.

38. Goldbohm RA, Brants HAM, Hulshof KFAM, Van den Brandt PA. The contribution of various foods to intake of vitamin $\mathrm{A}$ and carotenoids in the Netherlands. Int $\mathbf{J}$ Vit Nutr Res, 1998; 68: 378-383.

39. Sasaki S, Kobayashi M, Tsugane S. Development of sub- 
stituted fatty acid food composition table for the use in nutritional epidemiologic studies for Japanese populations: its methodological backgrounds and the evaluation. J Epidemiol, 1999; 9: 190-207.

40. Arai Y, Watanabe S, Kimira M, et al. Dietary intakes of flavonols, flavones and isoflavones by Japanese women and the inverse correlation between quercetin intake and plasma LDL cholesterol concentration. J Nutr, 2000; 130 : 2243-2250.

41. Ritenbaugh C, Peng YM, Aickin M, et al. New carotenoid values for foods improve relationship of food frequency questionnaire intake estimates to plasma values. Cancer Epidemiol Biomarkers Prev, 1996; 5: 907-912.

42. Van den Langenberg GM, Brady WE, Nebeling LC, et al. Influence of using different sources of carotenoid data in epidemiologic studies. J Am Diet Assoc, 1996; 96: 12711275.
43. Michaud DS, Giovannucci EL, Ascherio A, et al. Associations of plasma carotenoid concentrations and dietary intake of specific carotenoids in samples of two prospective cohort studies using a new carotenoid database. Cancer Epidemiol Biomarkers Prev, 1998; 7: 283-290.

44. Tsubono Y, Takamori S, Kobayashi M, et al. A databased approach for designing a semiquantitative food frequency questionnaire for a population-based prospective study in Japan. J Epidemiol, 1996; 6: 45-53.

45. Imaeda $N$, Tokudome $Y$, Ikeda $M$, et al. Foods contributing to absolute intake and variance in intake of selected vitamins, minerals and dietary fiber in middle-aged Japanese. J Nutr Sci Vitaminol, 1999; 45: 519-532.

46. Ascherio A, Stampfer MJ, Colditz GA, et al. Correlations of vitamin $\mathrm{A}$ and $\mathrm{E}$ intakes with the plasma concentrations of carotenoids and tocopherols among American men and women. J Nutr, 1992; 122: 1792-1801. 